\title{
The Galanin and Galanin Receptor Subtypes, its Regulatory Role in the Biological and Pathological Functions
}

\author{
J. ŠÍPKOVÁ ${ }^{1}$, I. KRAMÁRIKOVÁ ${ }^{1}$, S. HYNIE ${ }^{1}$, V. KLENEROVÁ ${ }^{1}$ \\ ${ }^{1}$ Laboratory of Neuropharmacology, Institute of Medical Biochemistry and Laboratory Diagnostics, \\ First Faculty of Medicine, Charles University, Prague, Czech Republic
}

Received December 16, 2016

Accepted March 31, 2017

On-line July 18, 2017

\section{Summary}

The multitalented neuropeptide galanin was first discovered 30 years ago but initially no biologic activity was found. Further research studies discovered the presence of galanin in the brain and some peripheral tissues, and galanin was identified as a modulator of neurotransmission in the central and peripheral nervous system. Over the last decade there were performed very intensive studies of the neuronal actions and also of nonneuronal actions of galanin. Other galanin family peptides have been described, namely galanin, galanin-like peptide, galanin-message associated peptide and alarin. The effect of these peptides is mediated through three galanin receptors subtypes, GalR1, GaIR2 and GalR3 belonging to G protein coupled receptors, and signaling via multiple transduction pathways, including inhibition of cyclic AMP/protein kinase A (GalR1, GalR3) and stimulation of phospholipase $C$ (GalR2). This also explains why one specific molecule of galanin can be responsible for different roles in different tissues. The present review summarizes the information currently available on the relationship between the galaninergic system and known pathological states. The research of novel galanin receptor specific agonists and antagonists is also very promising for its future role in pharmacological treatment. The galaninergic system is important target for current and future biomedical research.

\section{Key words}

Galanin • Galanin receptor • Neurotransmission • Galaninergic system • Regulatory function

\section{Corresponding author}

V. Klenerová, Laboratory of Neuropharmacology, Institute of Medical Biochemistry and Laboratory Diagnostics, First Faculty of Medicine, Charles University, Albertov 4, 12800 Prague 2, Czech Republic. Tel/Fax: +420 224968 166, +420 224968142 . E-mail: vera.klenerova@lf1.cuni.cz

\section{Introduction}

The galaninergic system is one of the specific signaling systems involved in neurotransmission and neuromodulation. The principal molecule of this system is the neuropeptide galanin. Galanin molecule was firstly described more than thirty years ago in the porcine intestine (Tatemoto et al. 1983) and this was promptly followed by major mapping studies. The distribution of galanin was reported in the widespread areas in the rat central nervous system and peripheral tissues and the presence of galanin was confirmed in many other species (Lang et al. 2015). Galanin is a principal signaling molecule of the galanin family, so called the galaninergic system, and today the galanin family consists of galanin, galanin-like peptide (GALP), alarin and galanin-message associated peptide (GMAP). The peptide GMAP is actually the precursor protein for the galanin molecule itself and the two possible products of different GALP gene: galanin-like peptide and its alternative form alarin (Webling et al. 2012).

Three different types of galanin receptors galanin receptor 1 (GalR1), galanin receptor 2 (GalR2) 
and galanin receptor 3 (GalR3) have been described so far (Branchek et al. 2000). All of them are members of the $G$ protein-coupled family and are involved in the biosignal transduction. The galaninergic receptors are widely expressed in the mammalian central nervous tissue; however, the presence of these receptors was also confirmed in many peripheral tissues, including the heart, gastrointestinal tract, connective tissue and skin (Lang et al. 2007). You can find more details in the part of this review concerning the galanin receptors.

The galaninergic system has been implicated in many biologically diverse functions including arousal/sleep regulation, nociception, learning and memory, depression, inflammation, feeding, pituitary hormone release, stress and anxiety, osmotic regulation and water intake, thermoregulation, reproduction and many others like different parts of metabolism (Fang et al. 2012). Also several human diseases, including Alzheimer's disease, epilepsy, diabetes mellitus and chronic pain are associated with the disturbance of the galaninergic system (Branchek et al. 2000, Lang et al. 2007). The research of galanin and its agonists and antagonists is also very promising for its future role in pharmacological treatment.

The galaninergic system is one of the crucial research topics of our laboratory. We are dealing with the regulatory issues of different neuropeptides (including galanin) in the central nervous system and various peripheral tissues (Klenerova et al. 2008, Klenerova et al. 2009). The behavioral part of the research activities mostly deals with the research of stress and anxiety using selected animal models (Klenerova et al. 2011, Klenerova et al. 2017). The research is performed on many different levels, including molecular genetic analysis, cell biology, immunofluorescence, immunohistochemistry and various animal tests. One of the main goals of this research is the possibility of future therapeutic use of synthetically prepared modulators of neurotransmission.

\section{Galanin and galanin receptors}

\section{Galanin, structure and genes}

The neuropeptide galanin is usually composed of 29 amino acids (Fig. 1) (Lang et al. 2007). This applies e.g. for the rat, the porcine or the bovine galanin which all contain a $\mathrm{C}$-terminal amidated glycine. The human galanin molecule is an exception, since it has a C-terminal nonamidated serine and contains 30 amino acids in total (Schmidt et al. 1990, Branchek et al. 2000).
Human galanin molecule is derived from a 123 amino acid long precursor pro-peptide along with a 59 or 60 amino acid peptide. This peptide is known as galanin message-associated peptide (GMAP) (Lang et al. 2007) and his biological function is mentioned in the next paragraph. The galanin precursor peptide is coded by a single gene, which includes 6 small exons (Kofler et al. 1996). Human galanin molecule is coded by the galanin gene, which was localized by Evans and Shine (1991) to human chromosome 11q13.3.



Fig. 1. Three dimensional structure of the galanin molecule.

The galanin molecule is usually composed of 29/30 amino acids, C-terminally amidated peptide. The isolated peptide was named galanin because of its $\mathrm{N}$-terminal glycine and C-terminal alanine residue. Galanin is proteolytically processed from a 123- (porcine, human) or 124- (murine and others) amino acid precursor pro-peptide, "preprogalanin", encoded by a single-copy gene (Evans and Shine 1991).

\section{Other neuropeptides of the galanin family}

A few other proteins have been described to play a role in the galaninergic system signalization. The most important of these proteins is the galanin-like peptide (GALP). GALP is a 60 amino acid long neuropeptide, originally discovered as an endogenous ligand for galanin receptors in the tissues of the porcine hypothalamus and gastrointestinal tract (Ohtaki et al. 1999, Lawrence and Fraley 2011). The GALP gene contains 6 exons in total and its primary structure is quite similar to the structure of the galanin gene (Kageyama et al. 2005). The effects of GALP are mediated by galanin receptor subtypes. The 
fact that GALP shares homology only with 13 amino acids of the galanin sequence suggests that it might also interact with its own specific receptor. GALP appears to be involved in feeding regulation, energy balance control and reproduction (Kageyama et al. 2005).

The second member of this group of alternative protein ligands is the newly described peptide called alarin. Alarin is a peptide composed of 25 amino acids and was firstly described in the tissue of human neuroblastic tumors. Alarin is actually a result of the process of alternative splicing of the GALP gene mRNA molecule (Santic et al. 2006). The roles of alarin seem to be mediated by unknown specific alarin receptors, as alarin lacks homology to galanin, and is unable to compete with galanin for known galanin receptors. Little is known regarding the physiological role or pharmacological properties of alarin. To date, the only reported in vivo effects of alarin are to promote vasoconstriction and anti-edema activity, the stimulation of food intake and the hypothalamo-pituitary-gonadal axis in rats (Boughton et al. 2010).

The original protein result of the galanin gene transcription is called galanin message-associated peptide (GMAP) (Lang et al. 2007). GMAP is not only the precursor molecule for the galanin creation, but the GMAP was also reported to have different biological functions, the potential role in nociception and immunomodulation was mentioned. However, the complex mechanisms of these biological interactions are not yet fully understood (Webling et al. 2012).

\section{Galanin receptors}

So far three main types of specific galanin receptors: GalR1, GalR2 and GalR3 have been described in the living organisms (Branchek et al. 2000). All three of them are different members of the G protein-coupled receptor (GPCR) family. However, their molecular structure, and involvement in the biosignal transduction is different and therefore also their roles in various organs/tissue physiology are rich and pleiotropic (Fig. 2). Potential association of any of previously discovered orphan receptors and the galaninergic system remain to be proved.

\section{Galanin receptor type 1}

The GalR1 molecule was described as the first known galanin receptor ever in the human melanoma cells (Habert-Ortoli 1994). Two years later the same receptor was also identified in the cells of the human gastrointestinal tract (Lorimer and Benya 1996). Human GalR1 protein is coded by the GalR1 gene, which is localized on human chromosome 18q23 (Nicholl et al. 1995). The human GalR1 protein itself is composed of 349 amino acids in total: for example the rat GalR1 homologue contains only 346 amino acids and has $92 \%$ similarity with human GalR1 (Branchek et al. 2000).

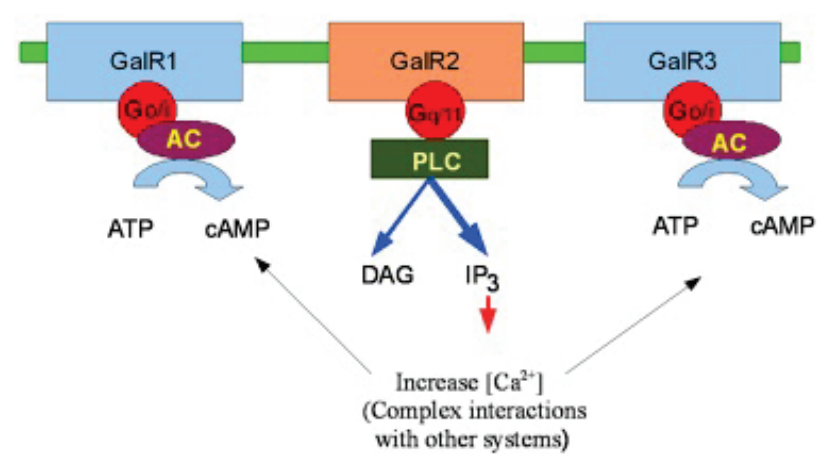

Fig. 2. The galanin receptors act through stimulation of different second messenger systems. The biological activity of GaIR1 and GalR3 stimulation is linked to the activity of adenylate cyclase and cyclic AMP (CAMP) production and stimulation of GaIR2 receptor to the phospholipase $C$ (PLC) activity. Gal receptors affect various classes of intracellular $\mathrm{G}$ proteins and influence multiple signal transduction pathways. Based on several presentations Klenerová and Hynie (Klenerova 2013, Klenerova and Hynie 2013, Klenerova and Hynie 2015).

The biological activity of GalR1 stimulation is linked to the activity of adenylate cyclase and cAMP production. Another result of this receptor activation on the cellular level was the prolonged activation of extracellular signal-regulated kinases 1 and 2 (ERK1/2) via $\mathrm{G} \alpha$ inhibitory-subunits (Gi), which modified the expression of cyclic-dependent kinase inhibitor proteins p27Kip1 and p57Kip2, with consequent inhibition of cell proliferation. These data support the concept that GalR1 is a likely tumor suppressor in cancer cells (Kanazawa et al. 2007). Additionally, internalization of GalR1 receptor was observed in transfected Chinese hamster ovary cells (Wang et al. 1997). This could be a possible mechanism (or one of such mechanisms) for regulating the endogenous galanin signaling cascade.

\section{Galanin receptor type 2}

The second identified galanin receptor 2 was initially isolated in the form of an expressed cDNA from the tissue of rat (Smith et al. 1997). The later discovered human GalR2 receptor is composed of 387 amino acids - which is 15 more than the originally described rat GalR2 homologue (Bloomquist et al. 1998). The human 
GalR2 is coded by the GaLR2 gene which was mapped to human chromosome 17q25.3 (Fathi et al. 1997, Fathi et al. 1998).

Also the stimulation of GalR2 receptor affects various classes of intracellular $G$ proteins and influences multiple signal transduction pathways. The most commonly reported - and probably the most important, pathway mediates the activation of the phospholipase $\mathrm{C}$ (PLC) which later increases the hydrolysis of inositol phosphate (Fathi et al. 1997). Also other interactions of GalR2 with Gi proteins were already reported. The GalR2 stimulation also leads to the inhibition of adenylate cyclase via Gi proteins, which is similar to the process of GalR1 stimulation (Wang et al. 1997). GalR2 receptor signalizing pathways was also reported to interact with Go-type G protein which activates mitogen activated protein kinase (MAPK) (Hawes et al. 2006). It was also found, that both GalR1 and GalR2 activation inhibits cyclic AMP-responsive element-binding (CREB) protein (Badie-Mahdavi et al. 2005). Another interesting result of the GalR2 stimulation is the supposed association with neuronal survival process, which is probably regulated by the AKT signaling pathway. AKT - also referred to as PKB or Rac, plays a critical role in controlling survival and apoptosis (Ding et al. 2006).

\section{Galanin receptor type 3}

Galanin receptor type 3 was described as the last known of the galanin receptors. It was initially cloned from the rat tissue and described by Smith et al. (1998). The rat GalR3 cDNA codes for a protein composed of 370 amino acids, the similarity between rat GalR3 and GalR1 molecules is $36 \%$ and between GalR3 and GalR2 molecules is $55 \%$ (Lee et al. 1999). The human GalR3 was firstly cloned by Kolakowski et al. (1998) using the human genomic DNA library according to the sequence similarity between GalR1 and GalR2 genes. Using the high-resolution fluorescent in situ hybridization (FISH) the human GalR3 gene was mapped to human chromosome 22q12.2-13.1. Human GalR3 protein contains 368 amino acids in total and has $90 \%$ similarity to rat GalR3 protein amino acid sequence (Kolakowski et al. 1998). The biological effects of the GalR3 signalization are still not fully understood and are subject to further research. In general, the pharmacology effects of the GalR3 combine the effects of GalR1 and GalR2 signalization (Branchek et al. 2000). GalR3 probably interacts with Gi/o-type $\mathrm{G}$ protein in order to stimulate the activation of an inward K+ influx (Kolakowski et al. 1998).
Non-peptide agonists of galanin receptors

So far we have mentioned the peptide agonists of the galanin receptors. Most galanin receptor ligands available today are peptides, vulnerable to enzymatic degradation and unable to cross the blood-brain barrier. However, there is also a small group of non-peptide agonists of galanin receptors (Bartfait et al. 2004). So far two different non-peptide general agonists - called galmic and galnon (Fig. 3) - were described. Their effect seems to be limited because of their multiple interaction sites and more research is needed to determine whether they have any important biological role or not (Webling et al. 2012). In addition to these two above agonists, there have been described two competitive antagonists of GalR3, SNAP 37889 (IUPAC Name 1-phenyl-3-[3(trifluoromethyl)phenyl]iminoindol-2-one) and its analog SNAP 398299 (IUPAC Name 1-[3-(2-pyrrolidin-1ylethoxy)phenyl]-3-[3-(trifluoromethyl)phenyl]imino-indol-2-one which is more water-soluble. These selective antagonists may represent an additional class of therapeutic agents for the treatment of anxiety, depression and cognitive dysfunction (Swanson et al. 2005) and the potentional treatment of alcohol use and eating disorders (Ash et al. 2011).

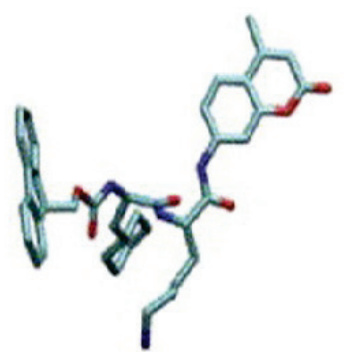

Fig. 3. Structure of galnon. A low molecular weight galanin receptor agonist galnon, 7-((9-fluorenylmethoxycarbonyl) cyclohexylalanyllysyl)amino-4-methylcoumarin (IUPAC name 9H-fluoren-9-ylmethyl $\mathrm{N}-[(2 S)-1-([(2 S)-6$-amino-1-[(4-methyl-2oxo-oxochromen-7-yl)amino]-1-oxohexan-2-yl]amino)-3-cyclohexyl-1-oxopropan-2-yl]carbamate) was discovered by application of a combinatorial library approach. Galnon possesses agonist properties in vitro and in vivo and strong anticonvulsant properties in vivo (Saar et al. 2002).

GalR2 positive allosteric modulator CYM2503 (9H-fluoren-9-yl)methyl((S)-1(((S)-6(tert-butoxycarbonyl)amino-1-((4-methyl-2-oxo-1,2-dihydroquinolin-7-yl) amino)-1-oxohexan-2-yl)amino])-3-cyclohexyl-1-oxopropan-2-yl)carbamate) have been shown to potentiate the anticonvulsant activity of endogenous galanin in mouse seizure models (Lu et al. 2010) and series of 2,4,6-triaminopyrimidines (Lang et al. 2015). However, 
the potential therapeutical use of these ligands is currently limited. More research will be needed.

\section{Galanin receptors distribution and actions under physiological conditions and in the pathology}

The distribution of galanin receptors of all three types were described in various mammalian organs and tissues and recently the aspects of galanin actions have been frequently studied in many areas by several laboratories. Galanin is associated with a lot of central and peripheral receptor-mediated actions including feeding, pain and anterior pituitary hormone regulation, the energy and osmotic homeostasis (Landry et al. 2000), reproduction (Gundlach 2002), and cognition (Kinney et al. 2002).

The diverse actions of galanin make this peptidergic system an attractive target for modulating obesity, cognitive deficits, analgesia and pituitary dysfunction etc. In the next part of this review we describe the data selected tissues and organs.

\section{Distribution of the GalRs in central nervous system}

GalR1 and GalR2 are widely expressed in the mammalian central nervous system (CNS) (Lang et al. 2007). GalR1 was found in the thalamus, the hypothalamus, the amygdala, the olfactory structures, the pons, the medulla and the spinal cord (Hohmann et al. 2003). The mRNA of GalR2 is broadly transcribed in the CNS as well, mainly in hippocampus, gyrus dentatus and nucleus arcuatus, supraopticus and corpora mammillaria, spinal trigeminal tract and in the dorsal vagal complex (Burazin et al. 2000). The overall expression of the GalR3 in the CNS is low, with the only exception of the hypothalamus (Mennicken et al. 2002). Other roles of the galaninergic system signalization in the CNS include the hypothalamic regulation of sleep and arousal processes (McGinty and Szymusiak 2003).

\section{Behavioral processes and anxiety}

As a neurotransmitter - galanin was described to affect numerous neurophysiological and behavioral processes. The involvement of galanin in regulation of anxiety and stress is probably one of its most important roles. Numerous studies have reported that galanin administration in the CNS produced an anxiolytic effect (e.g. Bailey et al. 2007, Klenerova et al. 2011). For example, the general anxiolytic effect of galanin administered bilaterally into the area of the central amygdala was experimentally successfully blocked by the galanin antagonist M40 in laboratory rats (Khoshbouei et al. 2002). This anxiolytic effect of galanin was also confirmed in the transgenic (and galanin over-expressing) mice model experiment, where the targeted induction of anxiety with yohimbine substance was impaired. One possible explanation is the reduced levels of noradrenalin and glutamate in the amygdala and the hippocampus (Holmes et al. 2002). Another study has shown that the selective GalR3 antagonists have produced anxiolytic effects in rats, mice and guinea pigs, possibly by attenuating the inhibitory effect of galanin (Swanson et al. 2005).

Substantial evidence has been obtained that implicates galanin signaling in reward, addictive processes and eating disorders. The selective galanin antagonists are the potential drugs of treatment of alcohol use and eating disorders (Ash et al. 2011).

Neural circuits that affect both stress-related and feeding behavior have been shown to be involved in drug reward behavior and substance abuse and addiction and are known to be modulated by galanin (Picciotto et al. 2010). GalRs may be attractive targets for the development of novel therapeutics for drug addiction.

\section{Regulatory role of galaninergic system in learning and memory}

The role of galaninergic system in learning and memory is also well documented in the literature (Lang et al. 2007). It has been shown, that galanin can produce deficits in behavioral performance. Central injection of galanin impaired the process of memory formation and impaired the ability of laboratory rats to perform learning tasks such as the classical Morris water maze (Sundstrom et al. 1988). This effect was further studied in different transgenic galanin-overexpressing mice strains. These mice had significant deficits in learning and memory tests (including spatial navigation and olfactory tests) and also in emotional memories which depend on glutamate release from the hippocampus (Mazarati et al. 2000). Nevertheless, the sensory and motor abilities, as well as the levels of extracellular noradrenaline and serotonin in the hippocampus were normal (Crawley et al. 2002).

\section{Distribution of the GalRs in peripheral nervous system}

The galaninergic neurotransmission system plays an important role also in the peripheral nervous system (Lang et al. 2007) where galanin was reported to 
be involved in the regenerative process following the nerve injury (Ahren et al. 2006). The expression of galanin and its receptors is also extensively elevated in the areas of nerve injury (Lang et al. 2007). This phenomenon was described by several authors in different animal models - including models of motor and sensory nerve axotomy or crush (Burazin and Gundlach 1998), central nerve transection (Palkovits and Horvath, 1994) or a focal cerebral ischemia (Raghavendra Rao et al. 2002).

\section{Regulatory role of galaninergic system in nociception} and pain

Galanin mediated neurotransmission also affects several processes in the peripheral nervous system, mainly in the process of nociception and pain in general. Galanin can act both as an inhibitory and excitatory mediator in the nociception process, where the final type of the outcome depends on several variables, like the chronicity of the pain stimulus, the nature (type) of the stimulus or the concentration of galanin in the peripheral nerve area (Liu and Hökfelt 2000, Flatters et al. 2003). It has been shown, that the adults of galanin knock-out mice experimental model have greater sensitivity to acute pain, while galanin overexpressing transgenic mice have reduced responses to acute thermal pain (Blakeman et al. 2001, Holmes et al. 2003).

Galanin receptors in heart and central cardiovascular control

Some evidence suggests that Gal may play role in central cardiovascular control, probably acting through different receptor subtypes, but exact mechanism of the action in the heart is not fully elucidated. In our study we have shown the presence of Gal and GALP in left and right atria and ventriculi (Klenerova et al. 2014), Gal mostly on plasma membranes of cardiomyocytes and GALP at intercalated discs. To detect intercalated disc we used immunofluorescent detection of Connexin 40. We determined of GalR subtypes in all heart compartments with the largest expression for GalR2 in plasma membranes and nuclei and the lowest for GalR3 in plasma membranes. GalR1 is expressed most intensively in nuclei and also in intercalated discs, in membranes was expression small. The results show different distribution and density of Gal receptors in the heart areas. These findings would suggest that the efficacy of Gal and GALP to induce an effective coupling of its receptors to $G$ proteins could be different depending on the heart localization. The galanin infusion in humans induced an increase in heart rate (dose dependent) and blood pressure. The galanin antagonist M40 blocks the hypertension induced by Gal (1-15), but not the cardiovascular effects induced by Gal. Although both GalR1 and GalR3 are present in cardiac ganglia, it was suggested that GalR1-activation reduces acetylcholine release from atrial cholinergic neurons (Lang et al. 2015).

\section{Gastrointestinal tract and pancreas}

In the gastrointestinal tract galanin modulates numerous activities, including regulation of transmitter release, secretion and motility. The expression of GalR1 and GalR2 mRNAs were detected in all segments with the highest levels in the large intestine and stomach, respectively. GalR3 mRNA levels were quite low and mostly confined to the colon. The differential distribution of galanin receptors supports the concept that the different effects of galanin suggest the activation of multiple receptor subtypes (Anselmi et al. 2005).

Galanin itself was isolated from pancreas islet cells and pancreatic nerves (McDonald et al. 1992). $\beta$-cells contain mRNA to encode all three galanin receptor subtypes. The role of galanin signalization in pancreas is very complex. Both galanin knockout and GalR1 gene-knockout mice models have shown impaired glucose metabolism (Ahren et al. 2004). In patients with diabetes mellitus type II there was a strong positive correlation of the galanin and glucose plasma levels in the fasting state (Legakis et al. 2005). Additionally, the study on special mice galanin gene knockout model proved that the galanin neurotransmission also takes part in the pathogenesis of acute pancreatitis (Bhandari et al. 2010).

\section{Bone and joint tissue cells}

Galanin and the expression of GalRs were detected in the bone (McDonald et al. 2003, Lang et al. 2007). Galanin can facilitate bone formation and enhance repair efficacy after osseous injury, the injection of galanin into the calvaria increased the number and the activity of osteoblasts in mice (McDonald et al. 2007). After bone fracture galanin receptor expression galanin concentration were increased in osteoblast-like cells (McDonald et al. 2003). Systemic administration of galnon, a galanin receptor agonist, may stimulate osteoclastic activity, increase resorptive speed of the osteoclastic bone (McGowan et al. 2014). 
Regulatory role of galaninergic system in other systems

The galanin was found even in the most peripheral of the tissues and surprisingly, the galaninergic receptors themselves are very scarce in the skin (Kofler et al. 1996). The role of galanin in the skin is therefore still not very well understood. Galanin probably influences the skin immunity, a significant increase of galanin was found in the inflamed skin. Furthermore, the GMAP peptide has some antimicrobial activity against Candida albicans and alarin has similar activity against Escherichia coli (Lang et al. 2015).

Galanin has also probably a significant role in the ontogenetic development (Lang et al. 2015). Various studies reported a dynamic expression of galanin and its receptors in the stem cells. This phenomenon was first described in the mice stem cells (Anisimov et al. 2002) and later also in human stem cells and even in cancer cells (Assou et al. 2007). The overall expression of galanin during embryonic development decreases steadily, which means, that the galanin signalization itself may be linked to the potential of the stem cells (Bhattacharya et al. 2005).

\section{The role of galanin in human diseases}

The role of galanin and the galaninergic system itself was already discovered in pathophysiology of several human diseases, namely Alzheimer's disease, diabetes and epilepsy. The brain in individuals with Alzheimer's disease is characterized by various neurofibrillary tangles and neural plaques. It was described that this degeneration of the neuronal collateral network leads to extensive upregulation of galanin expression in the remaining neurons mainly in the basal forebrain (Chan-Palay 1988). However, it is still not clear whether this upregulation is actually a contributing factor to the disease, mere result of the nerve injury, or maybe even a compensatory action to maintain cholinergic transmission (Lang et al. 2007). Epileptic seizures have been shown to rapidly deplete galanin. Galanin role in epilepsy and seizures is again very complex and not yet fully understood. It was shown that the activation of GalR1 is anticonvulsant, while the GalR2 activation is proconvulsant. Spontaneous seizures have been already described in the GalR1 knockout mice experimental model, whereas the seizures are absent at all in the galanin knockout mice model (Mazarati et al. 2000, Fetissov et al. 2003).

Another newly described role of galanin signalization concerns the oncology issue. Expression of galanin has been identified in several types of human tumors, namely pheochromocytoma, pituitary adenoma, neuroblastic tumors, gastrointestinal cancer, squamous cell carcinoma, brain tumors, melanoma, breast cancer and embryonal carcinoma (Rauch and Kofler 2010). The more detailed role of the galaninergic signalization in colorectal cancer invasiveness has been described recently (Nagayoshi et al. 2015). The co-expression of galanin and its receptors with variety neuropeptides supports a role for galanin in tumor cell pathology via autocrine/paracrine mechanisms (Berger et al. 2004).

As has been already mentioned, neuropeptide expression (including expression of galanin peptide and alarin) has been proven in various tumors. It has been shown, that the expression levels correlate with the level of differentiation or aggressiveness of the tumor. It is supposed that neuropeptides may show pro- or antiproliferative activity on cancer cells and so a therapeutic use could be possible (Lang et al. 2015).

Possible therapeutic effect of triple treatment with octreotide, galanin and serotonin on colorectal cancer has been studied. The triple therapy was shown effective in animal model in the treatment of human colon cancer xenografts. The volume and weight of rat as well as human colon carcinoma in xenografts has been reduced - by necrosis, induced apoptosis and reduced proliferation and expression of epidermal growth factor receptor (EGFR) of cancer cells. However, there will be need of further clinical trials to confirm benefit of this usage (El-Salhy 2005). The galaninergic system may also play role in other human diseases, namely alcoholism, chronical pain, bowel and skin inflammatory diseases (Lang et al. 2007).

\section{Potential therapeutic usage of galanin family}

Galanin has numerous and pleiotropic biological roles including various involvements in human diseases as described above. Galanin receptors agonists and antagonists are therefore promising substances for future pharmacologic treatment, namely for example as potential anticonvulsants (Saar et al. 2002, Webling et al. 2012). The research on this field is very broad; however there are still many problems in designing potential human drugs that we need to overcome first. It is not only the problem of the therapeutic usage of the galaninergic system modulation; this issue extends to the neurotransmitter system in general (Lang et al. 2015). 
The issues include relative heterogeneity of neurotransmitter molecules among species which is considerable complication for drug trials. Moreover, the molecules of different neurotransmitters are too big to pass the hematoencephalic barrier, so the central effect of such drug shall be considerably limited. Additionally, the general effect of neurotransmitters agonists can be potentially harmful, since such a drug will stimulate all receptors at once. On the other, antagonists can primarily affect the pathologically up-regulated areas of particular neurotransmission first (Lang et al. 2015). In addition, future research on galanin pathophysiology will be best advanced by the application of novel experimental tools and approaches.

\section{Conclusions}

The galaninergic neurotransmission system is one of the newly described signaling systems. The principal signaling molecule is the neuropeptide galanin and 3 different types of cell surface galanin receptors have been described in different types of organs and tissues so far. Galanin receptor stimulation starts the $G$ protein mediated cell signalization cascades and has pleiotropic effect both on the level of cell, tissue and organism itself. Several human diseases, including Alzheimer's disease, diabetes mellitus and epilepsy, have been already reported to be associated with disturbances in the galaninergic system signaling. Therefore galanin and its receptors present a promising target for pharmacology research and future treatment possibilities. This review will attempt to summarize the significant body of in vitro and in vivo studies conducted so far, concerning the effects of galaninergic system.

\section{Conflict of Interest}

There is no conflict of interest.

\section{Acknowledgements}

This study was supported by the grants PROGRES Q25/LF1 and SVV-2017-260377 from Charles University, Prague, Czech Republic.

\section{References}

AHREN B, PACINI G, WYNICK D, WIERUP N, SUNDLER F: Loss-of-function mutation of the galanin gene is associated with perturbed islet function in mice. Endocrinology 145: 3190-3196, 2004.

AHREN B, WIERUP N, SUNDLER F: Neuropeptides and the regulation of islet function. Diabetes 55 (Suppl 2): S98-S107, 2006.

ANISIMOV SV, TARASOV KV, TWEEDIE D, STERN MD, WOBUS AM, BOHELER KR: SAGE identification of gene transcripts with profiles unique to pluripotent mouse R1 embryonic stem cells. Genomics 79: 169-176, 2002.

ANSELMI L, STELLA SL JR, LAKHER A, HIRANO A, TONINI M, STERNINI C: Galanin receptors in the rat gastrointestinal tract. Neuropeptides 39: 349-352, 2005.

ASH BL, ZANATTA SD, WILLIAMS SJ, LAWRENCE AJ, DJOUMA E: The galanin-3 receptor antagonist, SNAP 37889, reduces operant responding for ethanol in alcohol-preferring rats. Regul Pept 166: 59-67, 2011.

ASSOU S, LE CARROUR T, TONDEUR S, STRÖM S, GABELLE A, MARTY S, NADAL L, PANTESCO V, RÉME T, HUGNOT JP, ET AL.: A meta-analysis of human embryonic stem cells transcriptome integrated into a web-based expression atlas. Stem Cells 25: 961-973, 2007.

BADIE-MAHDAVI H, LU X, BEHRENS MM, BARTFAI T: Role of galanin receptor 1 and galanin receptor 2 activation in synaptic plasticity associated with 3',5'-cyclic AMP response element-binding protein phosphorylation in the dentate gyrus: studies with a galanin receptor 2 agonist and galanin receptor 1 knockout mice. Neuroscience 133: 591-604, 2005.

BAILEY KR, PAVLOVA MN, ROHDE AD, HOHMANN JG, CRAWLEY JN: Galanin receptor subtype 2 (GalR2) null mutant mice display an anxiogenic-like phenotype specific to the elevated plus-maze. Pharmacol Biochem Behav 86: 8-20, 2007.

BARTFAI T, LU X, BADIE-MAHDAVI H, BARR AM, MAZARATI A, HUA XY, YAKSH T, HABERHAUER G, CEIDE SC, TREMBLEAU L, ET AL.: Galmic, a nonpeptide galanin receptor agonist, affects behaviors in seizure, pain, and forced-swim tests. Proc Natl Acad Sci U S A 101: 10470-10475, 2004. 
BERGER A, SANTIC R, HAUSER-KRONGERGER C, SCHILLING FH, KOGNER P, RATSCHEK M, GAMPER A, JONES N, SPERL W, KOFLER B: Galanin and galanin receptors in human cancers. Neuropeptides 39: 353-359, 2005.

BHANDARI M, THOMAS AC, HUSSEY DJ, LI X, JAYA SP, WOODS CM, SCHLOITHE AC, MAYNE GC, CARATI CJ, TOOULI J, ORMANDY CJ, SACCONE GT: Galanin mediates the pathogenesis of cerulein-induced acute pancreatitis in the mouse. Pancreas 39: 182-187, 2010.

BHATTACHARYA B, CAI J, LUO Y, MIURA T, MEJIDO J, BRIMBLE SN, ZENG X, SCHULZ TC, RAO MS, PURI RK: Comparison of the gene expression profile of undifferentiated human embryonic stem cell lines and differentiating embryoid bodies. BMC Dev Biol 5: 22, 2005.

BLAKEMAN KH, HOLMBERG K, HAO JX, XU XJ, KAHL U, LENDAHL U, BARTFAI T, WIESENFELDHALLIN Z, HÖKFELT T: Mice over-expressing galanin have elevated heat nociceptive threshold. Neuroreport 12: 423-425, 2001.

BLOOMQUIST BT, BEAUCHAMP MR, ZHELNIN L, BROWN SE, GORE-WILLSE AR, GREGOR P, CORNFIELD LJ: Cloning and expression of the human galanin receptor GalR2. Biochem Biophys Res Commun 243: 474-479, 1998.

BOUGHTON CK, PATTERSON M, BEWICK GA, TADROSS JA, GARDINER JV, BEALE KE, CHAUDERY F, HUNTER G, BUSBRIDGE M, LEAVY EM, ET AL.: Alarin stimulates food intake and gonadotrophin release in male rats. British $J$ Pharmacol 161: 601-613, 2010.

BRANCHEK TA, SMITH KE, GERALD C, WALKER MW: Galanin receptor subtypes. Trends Pharmacol Sci 21: 109-117, 2000.

BURAZIN TC, GUNDLACH AL: Inducible galanin and GalR2 receptor system in motor neuron injury and regeneration. $J$ Neurochem 71: 879-882, 1998.

BURAZIN TC, LARM JA, RYAN MC, GUNDLACH AL: Galanin-R1 and -R2 receptor mRNA expression during the development of rat brain suggests differential subtype involvement in synaptic transmission and plasticity. Eur J Neurosci 12: 2901-2917, 2000.

CHAN-PALAY V: Galanin hyperinnervates surviving neurons of the human basal nucleus of Meynert in dementias of Alzheimer's and Parkinson's disease: a hypothesis for the role of galanin in accentuating cholinergic dysfunction in dementia. J Comp Neurol 273: 543-557, 1988.

CRAWLEY JN, AUSTIN MC, FISKE SM, MARTIN B, CONSOLO S, BERTHOLD M, LANGEL U, FISONE G, BARTFAI T: Activity of centrally administered galanin fragments on stimulation of feeding behavior and on galanin receptor binding in the rat hypothalamus. $J$ Neurosci 10: 3695-3700, 1990.

DING X, MACTAVISH D, KAR S, JHAMANDAS JH: Galanin attenuates beta-amyloid (Abeta) toxicity in rat cholinergic basal forebrain neurons. Neurobiol Dis 21: 413-420, 2006.

EL-SALHY M: Triple treatment with octreotide, galanin and serotonin is a promising therapy for colorectal cancer. Curr Pharm 11: 2107-2117, 2005.

EVANS HF, SHINE J: Human galanin: molecular cloning reveals a unique structure. Endocrinology 129: 1682-1684, 1991.

FATHI Z, BATTAGLINO PM, IBEN LG, LI H, BAKER E, ZHANG D, MCGOVERN R, MAHLE CD, SUTHERLAND GR, IISMAA TP, ET AL: Molecular characterization, pharmacological properties and chromosomal localization of the human GALR2 galanin receptor. Brain Res Mol Brain Res 58: 156-169, 1998.

FATHI Z, CUNNINGHAM AM, IBEN LG, BATTAGLINO PB, WARD SA, NICHOL KA, PINE KA, WANG J, GOLDSTEIN ME, IISMAA TP, ZIMANYI IA: Cloning, pharmacological characterization and distribution of a novel galanin receptor. Brain Res Mol Brain Res 51: 49-59, 1997.

FETISSOV SO, JACOBY AS, BRUMOVSKY PR, SHINE J, IISMAA TP, HÖKFELT T: Altered hippocampal expression of neuropeptides in seizure-prone GALR1 knockout mice. Epilepsia 44: 1022-1033, 2003.

FLATTERS SJ, FOX AJ, DICKENSON AH: In vivo and in vitro effects of peripheral galanin on nociceptive transmission in naive and neuropathic states. Neuroscience 116: 1005-1012, 2003.

GUNDLACH AL: Galanin/GALP and galanin receptors: role in central control of feeding, body weight/obesity and reproduction? Eur J Pharmacol 440: 255-268, 2002. 
HABERT-ORTOLI E, AMIRANOFF B, LOQUET I, LABURTHE M, MAYAUX JF: Molecular cloning of a functional human galanin receptor. Proc Natl Acad Sci U S A 91: 9780-9783, 1994.

HAWES JJ, NARASIMHAIAH R, PICCIOTTO MR: Galanin and galanin-like peptide modulate neurite outgrowth via protein kinase C-mediated activation of extracellular signal-related kinase. Eur J Neurosci 23: 2937-2946, 2006.

HOHMANN JG, JURÉUS A, TEKLEMICHAEL DN, MATSUMOTO AM, CLIFTON DK, STEINER RA: Distribution and regulation of galanin receptor 1 messenger RNA in the forebrain of wild type and galanintransgenic mice. Neuroscience 117: 105-117, 2003.

HOLMES A, YANG RJ, CRAWLEY JN: Evaluation of an anxiety-related phenotype in galanin overexpressing transgenic mice. J Mol Neurosci 18: 151-165, 2002.

HOLMES FE, BACON A, POPE RJ, VANDERPLANK PA, KERR NC, SUKUMARAN M, PACHNIS V, WYNICK D: Transgenic overexpression of galanin in the dorsal root ganglia modulates pain-related behavior. Proc Natl Acad Sci U S A 100: 6180-6185, 2003.

KAGEYAMA H, TAKENOYA F, KITA T, HORI T, GUAN JL, SHIODA S: Galanin-like peptide in the brain: effects on feeding, energy metabolism and reproduction. Regul Peptides 126: 21-26, 2005.

KANAZAWA T, IWASHITA T, KOMMAREDDI P, NAIR T, MISAWA K, MISAWA Y, UEDA Y, TONO T, CAREY TE: Galanin and galanin receptor type 1 suppress proliferation in squamous carcinoma cells: activation of the extracellular signal regulated kinase pathway and induction of cyclin-dependent kinase inhibitors. Oncogene 26: 5762-5771, 2007.

KHOSHBOUEI H, CECCHI M, DOVE S, JAVORS M, MORILAK DA: Behavioral reactivity to stress: amplification of stress-induced noradrenergic activation elicits a galanin-mediated anxiolytic effect in central amygdala. Pharmacol Biochem Behav 71: 407-417, 2002.

KINNEY JW, STAROSTA G, HOLMES A, WRENN CC, YANG RJ, HARRIS AP, LONG KC, CRAWLEY JN: Deficits in trace cued fear conditioning in galanin-treated rats and galanin-overexpressing transgenic mice. Learn Mem 9: 178-190, 2002.

KLENEROVA V: Regulatory Role of Galaninergic Neuropeptide System in the Anterior, Posterior and Intermediate

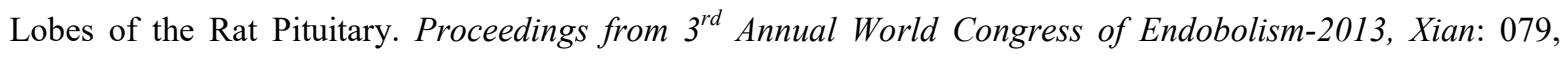
2013.

KLENEROVA V, HYNIE S: The effects of stress on galanin peptide system in the rat pituitary: expression of mRNA and immunohistochemistry of galanin receptor subtypes. Abstrakt Book from $10^{\text {th }}$ Göttingen Meeting of the German Neuroscience Society: T5-2C, 2013.

KLENEROVA V, HYNIE S: Galaninergic system and stress. Abstracts of the Eleventh Symposium on Catecholamines and Other Neurotransmitters in Stress, Smolenice Slovakia 2015, p. 33.

KLENEROVÁ V, HYNIE S: Galaninergic system and stress. Cell Mol Neurobiol (Special Issue "In Memoriam, Richard Kvetnansky", 2017), in press.

KLENEROVA V, KREJCI I, SIDA P, HLINAK Z, HYNIE S: Effects of melanotan II, a melanocortin agonist, on grooming and exploration in rats after repeated restraint/immobilization. Neurosci Lett 432: 202-205, 2008.

KLENEROVA V, KREJCI I, SIDA P, HLINAK Z, HYNIE S: Modulary effects of oxytocin and carbetocin on stressinduced changes in rat behavior in the open-field. J Physiol Pharmacol 60: 57-62, 2009.

KLENEROVA V, KREJCI I, SIDA P, HLINAK Z, HYNIE S: Oxytocin and carbetocin ameliorating effects on restraint stress-induced short- and long-term behavioral changes in rats. Neuro Endocrinol Lett 31: 622-630, 2010.

KLENEROVÁ V, FLEGEL M, ŠKOPEK P, ŠÍDA P, HYNIE S: Galanin modulating effect on restraint stress-induced short- and long-term behavioral changes in Wistar rats. Neurosci Lett 502: 147-151, 2011.

KLENEROVA V, SKOPEK P, HYNIE S: Galaninergic system in rat heart - perspective therapeutic target. Proceedings from the 17th World Congress of Pharmacology, Cape Town, South Africa, 2014.

KLENEROVÁ V, ŠÍPKOVÁ J, ŠÍDA P, KASPŘíKOVÁ N, KRAMÁRIKOVÁ I, HYNIE S: Effect of stress on the expression of galanin receptors in rat heart. Folia Biol (Praha) 63: 98-104, 2017.

KOFLER B, LIU ML, JACOBY AS, SHINE J, IISMAA TP: Molecular cloning and characterisation of the mouse preprogalanin gene. Gene 182: 71-75, 1996. 
KOLAKOWSKI LFJ, O'NEILL GP, HOWARD AD, BROUSSARD SR, SULLIVAN KA, FEIGHNER SD, SAWZDARGO M, NGUYEN T, KARGMAN S, SHIAO LL, ET AL:: Molecular characterization and expression of cloned human galanin receptors GALR2 and GALR3. J Neurochem 71: 2239-2251, 1998.

LANDRY M, ROCHE D, VILA-PORCILE E, CALAS A: Effects of centrally administered galanin (1-16) on galanin expression in the rat hypothalamus. Peptides 21: 1725-1733, 2000.

LANG R, GUNDLACH AL, KOFLER B: The galanin peptide family: receptor pharmacology, pleiotropic biological actions, and implications in health and disease. Pharmacol Ther 115: 177-207, 2007.

LANG R, GUNDLACH AL, HOLMES FE, HOBSON SA, WYNICK D, HÖKFELT T, KOFLER B: Physiology, signaling, and pharmacology of galanin peptides and receptors: three decades of emerging diversity. Pharmacol Rev 67: 118-175, 2015.

LAWRENCE C, FRALEY GS: Galanin-like peptide (GALP) is a hypothalamic regulator of energy homeostasis and reproduction. Front Neuroendocrinol 32: 1-9, 2011.

LEE DK, NGUYEN T, O'NEILL GP, CHENG R, LIU Y, HOWARD AD, COULOMBE N, TAN CP, TANGNGUYEN AT, GEORGE SR, O'DOWD BF: Discovery of a receptor related to the galanin receptors. FEBS Lett 446: 103-107, 1999.

LEGAKIS I, MANTZOURIDIS T, MOUNTOKALAKIS T: Positive correlation of galanin with glucose in type 2 diabetes. Diabetes Care 28: 759-760, 2005.

LIU H, HÖKFELT T: Effect of intrathecal galanin and its putative antagonist M35 on pain behavior in a neuropathic pain model. Brain Res 886: 67-72, 2000.

LIU HX, HÖKFELT T: The participation of galanin in pain processing at the spinal level. Trends Pharmacol Sci 23: 468-474, 2002.

LORIMER DD, BENYA RV: Cloning and quantification of galanin-1 receptor expression by mucosal cells lining the human gastrointestinal tract. Biochem Biophys Res Commun 222: 379-385, 1996.

LU X, ROBERTS E, XIA F, SANCHEZ-ALAVEZ M, LIU T, BALDWIN R, WU S, CHANG J, WASTERLAIN CG, BARTFAI T: GalR2-positive allosteric modulator exhibits anticonvulsant effects in animal models. Proc Natl Acad Sci U S A 107: 15229-15234, 2010.

MAZARATI AM, HOHMANN JG, BACON A, LIU H, SANKAR R, S TEINER RA, WYNICK D, WASTERLAIN CG: Modulation of hippocampal excitability and seizures by galanin. J Neurosci 20: 6276-6281, 2000.

MCDONALD TJ, BROOKS BD, ROKAEUS A, TINNER B, STAINES WA: Pancreatic galanin: molecular forms and anatomical locations. Pancreas 7: 624-635, 1992.

MCGOWAN HW, SCHUIJERS JA, GRILLS BL, MCDONALD SJ, MCDONALD AC: Galnon, a galanin receptor agonist, improves intrinsic cortical bone tissue properties but exacerbates bone loss in an ovariectomised rat model. J Musculoskelet Neuronal Interact 14: 162-172, 2014.

MCGINTY D, SZYMUSIAK R: Hypothalamic regulation of sleep and arousal. Front Biosci 8: 1074-1083, 2003.

MENNICKEN F, HOFFERT C, PELLETIER M, AHMAD S, O'DONNELL D: Restricted distribution of galanin receptor 3 (GalR3) mRNA in the adult rat central nervous system. $J$ Chem Neuroanat 24: 257-268, 2002.

NAGAYOSHI K, UEKI T, TASHIRO K, MIZUUCHI Y, MANABE T, ARAKI H, ODA Y, KUHARA S. TANAKA M: Galanin plays an important role in cancer invasiveness and is associated with poor prognosis in stage II colorectal cancer. Oncol Rep 33: 539-546, 2015.

NICHOLL J, KOFLER B, SUTHERLAND GR, SHINE J, IISMAA TP: Assignment of the gene encoding human galanin receptor (GALNR) to 18q23 by in situ hybridization. Genomics 30: 629-630, 1995.

OHTAKI T, KUMANO S, ISHIBASHI Y, OGI K, MATSUI H, HARADA M, KITADA C, KUROKAWA T, ONDA $\mathrm{H}$, FUJINO M: Isolation and cDNA cloning of a novel galanin-like peptide (GALP) from porcine hypothalamus. J Biol Chem 274: 37041-37045, 1999.

PALKOVITS M, HORVÁTH S: Galanin immunoreactive neurons in the medulla oblongata of rats. Acta Biol Hung $\mathbf{4 5}$ : 399-417, 1994.

PICCIOTTO MR: Galanin and addiction. EXS 102: 195-208, 2010.

RAUCH I, KOFLER B: The galanin system in cancer. EXS 102: 223-241, 2010. 
RAGHAVENDRA RAO VL, BOWEN KK, DHODDA VK, SONG G, FRANKLIN JL, GAVVA NR, DEMPSEY RJ: Gene expression analysis of spontaneously hypertensive rat cerebral cortex following transient focal cerebral ischemia. J Neurochem 83: 1072-1086, 2002.

SAAR K, MAZARATI AM, MAHLAPUU R, HALLNEMO G, SOOMETS U, KILK K, HELLBERG S, POOGA M, TOLF BR, SHI TS, ET AL.: Anticonvulsant activity of a nonpeptide galanin receptor agonist. Proc Natl Acad Sci U S A 99: 7136-7141, 2002.

SANTIC R, FENNINGER K, GRAF K, SCHNEIDER R, HAUSER-KRONBERGER C, SCHILLING FH, KOGNER P, RATSCHEK M, JONES N, SPERL W, KOFLER B: Gangliocytes in neuroblastic tumors express alarin, a novel peptide derived by differential splicing of the galanin-like peptide gene. J Mol Neurosc 29: 145-152, 2006.

SCHMIDT WE, KRATZIN H, ECKART K, DREVS D, MUNDKOWSKI G, CLEMENS A, KATSOULIS S, SCHÄFER H, GALLWITZ B, CREUTZFELDT W: Isolation and primary structure of pituitary human galanin, a 30-residue nonamidated neuropeptide. Proc Natl Acad Sci U S A 88: 11435-11439, 1991.

SMITH KE, FORRAY C, WALKER MW, JONES KA, TAMM JA, BARD J, BRANCHEK TA, LINEMEYER DL, GERALD C: Expression cloning of a rat hypothalamic galanin receptor coupled to phosphoinositide turnover. J Biol Chem 272: 24612-24616, 1997.

SMITH KE, WALKER MW, ARTYMYSHYN R, BARD J, BOROWSKY B, TAMM JA, YAO WJ, VAYSSE PJ, BRANCHEK TA, GERALD C, JONES KA: Cloned human and rat galanin GALR3 receptors. Pharmacology and activation of G-protein inwardly rectifying K+ channels. J Biol Chem 273: 23321-23326, 1998.

SUNDSTRÖM E, ARCHER T, MELANDER T, HÖKFELT T: Galanin impairs acquisition but not retrieval of spatial memory in rats studied in the Morris swim maze. Neurosci Lett 88: 331-335, 1988.

SWANSON CJ, BLACKBURN TP, ZHANG X, ZHENG K, XU ZQ, HÖKFELT T, WOLINSKY TD, KONKEL MJ, CHEN H, ZHONG H, WALKER MW, CRAIG DA, GERALD CP, BRANCHEK TA: Anxiolytic- and antidepressant-like profiles of the galanin-3 receptor (Gal3) antagonists SNAP 37889 and SNAP 398299. Proc Natl Acad Sci U S A 102: 17489-17494, 2005.

TATEMOTO A, RÖKAEUS A, JÖRNVALL H, MCDONALD TJ, MUTT V: Galanin - a novel biologically active peptide from porcine intestine. FEBS Lett 164: 124-128, 1983.

WANG S, HASHEMI T, HE C, STRADER C, BAYNE M: Molecular cloning and pharmacological characterization of a new galanin receptor subtype. Mol Pharmacol 52: 337-343, 1997.

WEBLING KE, RUNESSON J, BARTFAI T, LANGEL U: Galanin receptors and ligands. Front Endocrinol (Lausanne) 3: 146, 2012. 